University of Nebraska - Lincoln

DigitalCommons@University of Nebraska - Lincoln

USDA National Wildlife Research Center - Staff Publications
U.S. Department of Agriculture: Animal and Plant Health Inspection Service

2019

\title{
Locating and eliminating feral swine from a large area of fragmented mixed forest and agriculture habitats in north-central USA
}

\author{
Richard M. Engeman \\ USDA National Wildlife Research Center, s_r100@yahoo.com \\ Bradley E. Wilson \\ USDA APHIS Wildlife Services \\ Scott F. Beckerman \\ USDA APHIS Wildlife Services \\ Justin W. Fischer \\ USDA National Wildlife Research Center, Justin.w.fischer@aphis.usda.gov \\ Doug Dufford \\ Illinois Department of Natural Resources
}

See next page for additional authors

Follow this and additional works at: https://digitalcommons.unl.edu/icwdm_usdanwrc

Part of the Life Sciences Commons

Engeman, Richard M.; Wilson, Bradley E.; Beckerman, Scott F.; Fischer, Justin W.; Dufford, Doug; and Cobban, James Bryan, "Locating and eliminating feral swine from a large area of fragmented mixed forest and agriculture habitats in north-central USA" (2019). USDA National Wildlife Research Center - Staff Publications. 2221.

https://digitalcommons.unl.edu/icwdm_usdanwrc/2221

This Article is brought to you for free and open access by the U.S. Department of Agriculture: Animal and Plant Health Inspection Service at DigitalCommons@University of Nebraska - Lincoln. It has been accepted for inclusion in USDA National Wildlife Research Center - Staff Publications by an authorized administrator of DigitalCommons@University of Nebraska - Lincoln. 


\section{Authors}

Richard M. Engeman, Bradley E. Wilson, Scott F. Beckerman, Justin W. Fischer, Doug Dufford, and James Bryan Cobban 


\title{
Locating and eliminating feral swine from a large area of fragmented mixed forest and agriculture habitats in north-central USA
}

\author{
Richard M. Engeman ${ }^{1} \cdot$ Bradley E. Wilson ${ }^{2} \cdot$ Scott F. Beckerman ${ }^{2} \cdot$ Justin W. Fischer $^{1} \cdot$ Doug Dufford $^{3}$. \\ James Bryan Cobban ${ }^{2}$
}

Received: 18 April 2018 / Accepted: 6 November 2018 / Published online: 17 November 2018

(C) This is a U.S. government work and not under copyright protection in the U.S.; foreign copyright protection may apply 2018

\begin{abstract}
Illinois is one of the US states where elimination of feral swine (Sus scrofa) was determined practical, as only a few isolated populations were established. A particularly important step towards feral swine elimination from Illinois was to eliminate the population in Fulton County. We describe the approaches applied to systematically detect, locate, and eliminate feral swine in a successful county-wide elimination. Detecting and locating feral swine was facilitated by extensive outreach activities, aerial surveys to locate crop damage, and use of camera traps placed over bait in areas where reports, sign, or crop damage occurred. The population was eliminated after 376 feral swine were removed from 2009 to 2016 by trapping, sharpshooting over bait, and aerial shooting. Aerial surveys efficiently located feral swine activity over wide areas during times of the crop cycle when damage would occur and would be most distinguishable from other damage sources. Two applications of aerial shooting in 2014 were particularly efficient for rapidly eliminating most remaining feral swine after they had become difficult to locate and remove. Persistent efforts thereafter led to the successful elimination of feral swine in Fulton County by 2016. We believe this is the first documentation of a widespread feral swine elimination in mixed agriculture and forest habitats.
\end{abstract}

Keywords Aerial surveys $\cdot$ Illinois $\cdot$ IPM $\cdot$ Invasive species $\cdot$ Outreach $\cdot$ Sus scrofa $\cdot$ Wild pig $\cdot$ Wildlife damage management

\section{Introduction}

Feral swine (Sus scrofa) are one of the world's most destructive invasive species and are well-known globally for their damage to native habitats and plant species, archeological sites, preying on and competing with native animal species, and posing particular threats to endangered animal and plant species (Barrios-Garcia and Ballari 2012; Choquenot et al. 1996; Engeman et al. 2007, 2013, 2017; Seward et al. 2004; U.S. Department of Agriculture 2016), as well as harboring a

Responsible editor: Philippe Garrigues

Richard M. Engeman

richard.m.engeman@aphis.usda.gov

1 National Wildlife Research Center, 4101 LaPorte Ave, Fort Collins, CO 80521-2154, USA

2 USDA/APHIS-Wildlife Services, 3430 Constitution Drive, Suite 121, Springfield, IL 62711, USA

3 Illinois Department of Natural Resources, 8542 N. Lake Rd, Lena, IL 61048, USA number of diseases transmittable to wildlife, livestock, or humans (e.g., Leiser et al. 2013; U.S. Department of Agriculture 2016; Wyckoff et al. 2009). The global biological infamy of feral swine has resulted in their inclusion among the 100 "world's worst" invaders by the IUCN's Invasive Species Specialist Group (Lowe et al. 2004). The destructive capabilities of feral swine are matched by their reproductive fitness, as this species has the greatest reproductive potential of all free-ranging large mammals in North America, and perhaps the world (Bieber and Ruf 2005; West et al. 2009). There now are invasive feral swine populations in at least 35 of the 50 states in the USA (Corn and Jordan 2018; Snow et al. 2017; U.S. Department of Agriculture 2016).

Feral swine were first documented in Illinois in 1993 in Union County (Grund et al. 2000; McCann et al. 2003), and later observed in several other counties (Esker 2001; McCann et al. 2003). Because Illinois was one of the states where feral swine populations were low and only occurred in isolated portions of the state (U.S. Department of Agriculture/Animal and Plant Health Inspection Service 2015a, b), Illinois also was one of the states determined as most feasible and practical for statewide elimination of feral swine (U.S. Department of 
Agriculture/Animal and Plant Health Inspection Service 2015a). The locations of feral swine populations in Illinois were largely a reflection of where they had been released for hunting (McCann et al. 2003). Even when occurring in relatively small and isolated populations, feral swine have the potential to rapidly increase in density and distribution, especially when cover and food resources abound, making it essential to eliminate a potential problem while still practical to do so (e.g., Bieber and Ruf 2005; West et al. 2009).

Reports of feral swine had been confirmed by 2005 in Fulton County, where forest cover and food resources from both agricultural crops and forest were plentiful (McCann et al. 2003). Forest provides both cover and food for feral swine, while crops offer a bounty of nutrients and cover during seasonal phases of the crop cycle (McCann et al. 2003). Fulton County had the largest concentration of feral swine in the state, making elimination of its feral swine an especially essential step towards eliminating feral swine from Illinois. This important operational management activity also served to develop techniques for effective and practical approaches for successful feral swine elimination over a large area with an agriculture-woodland habitat mix. A prescribed protocol for eliminating feral swine from mixed habitats in an area the size of Fulton County was not available. Here, we describe and quantify the strategies, approaches, and methods tested and applied to systematically detect, locate, and eliminate the feral swine in Fulton County leading to a successful county-wide elimination. To our knowledge, this is the first documentation of a widespread feral swine elimination in mixed agriculture and forest habitats.

\section{Methods}

\section{Fulton County}

Fulton County is a $2290-\mathrm{km}^{2}$ county located in west-central Illinois. Fulton County landholdings are overwhelmingly in private ownership, as is the case for Illinois as a whole where nearly $96 \%$ of land is privately owned (US Bureau of the Census 1991). Forested and agricultural areas are the two most important habitat types for feral swine in Illinois, and the highly fragmented habitats in Fulton County present a balance of both (McCann et al. 2003). Reproduction is linked to nutrition, making areas with agriculture valuable for feral swine reproductive success (McCann et al. 2003). Moreover, the availability of agricultural crops has been found to be a key predictor for feral swine population establishment and growth (Webb et al. 2018). In 2009, the U.S. Department of Agriculture/Wildlife Services (WS), together with the Illinois Department of Natural Resources (IDNR), began working with private landowners to conduct feral swine disease surveillance in the state. In 2011, WS and the IDNR signed a cooperative service agreement (CSA), officially starting a collaboration to aggressively address the feral swine problem, including an initial focus on the self-sustaining feral swine population in Fulton County (WS and the IDNR also monitored the remainder of Illinois, investigating reports of feral swine as necessary).

\section{Outreach}

A wide variety of outreach activities were applied to educate the public about negative impacts of feral swine. Provisions of assistance to landowners, as well as educating and informing the public through a variety of avenues, were implemented to generate public support and cooperation and to further program expansion among landowners. Such outreach activities included distribution of leaflets, brochures, posters, instructional demonstrations, workshops, and sessions, as well as personal consultations. These outreach activities were conducted to bring face-to-face confidence and familiarity with landowners and the general public. Additional consultations were conducted by telephone or in writing, and positive news media in the form of radio and television appearances, press releases, and newspaper articles broadly informed the public. Feral swine damage management displays at events, such as outdoor recreation shows, provided further interaction with large numbers of people. All of these actions were used to raise awareness regarding the feral swine problem, how to report feral swine sightings, and obtain management assistance.

\section{Illinois DNR policy}

The IDNR implemented rules and procedures to promote feral swine elimination in the state. In an effort to greatly diminish the "value" of feral swine to the public, a new Administrative Code was enacted in 2014 to discourage recreational hunting for feral swine (CH. 1, SEC. 700.10-700.50). This rule made shooting feral swine outside of the state's firearm deer season illegal, provided regulations against transportation and/or release of feral swine, and required landowners experiencing damage to obtain a free nuisance wildlife removal permit to trap or shoot feral swine outside of the assigned season. Further, in 2015, IDNR augmented the Mandatory Deer and Wild Turkey Harvest Reporting System with the ability to report feral swine sightings. In this way, the IDNR also enlisted assistance from hunters to report feral swine locations.

\section{Trail cameras}

Motion activated trail cameras were used to identify feral swine in areas where they were likely to occur, especially in areas where reports of their activity (particularly rooting) had occurred, or where they had been observed and reported. 
Cameras were placed over bait consisting of soured corn. Bait sites at which feral swine were detected on camera were subsequently used as locations to erect traps or for sharpshooting. Camera data were used for the purposes of detection, followed as quickly as possible by removal. The frequency of visitation and the number of feral swine recorded by cameras were used to determine the most efficient on-the-ground removal method for that site.

\section{Aerial surveys}

Aerial surveys were conducted to search for feral swine damage to field corn as a means to provide insight into near realtime feral swine activity. This greatly aided in identification of areas where concentrated ground detection and survey methods, such as cameras, could be effectively applied to focus removal efforts. As such, the aerial surveys were strictly for locating areas with feral swine activity and were not designed nor intended for estimating damage amounts. Aerial surveys allowed the area to be thoroughly searched for feral swine damage in a little over $2 \mathrm{~h}$ of flight time.

Surveys were conducted by a helicopter on 4 September 2013, 16 September 2014, and 10 August 2015. Aerial surveys were conducted visually from an altitude between 150 and $230 \mathrm{~m}$ above ground level, with occasional excursions to lower altitudes to better evaluate specific sites. The average air speed was 70 knots for each survey. Flight times were between $2 \mathrm{~h} 10 \mathrm{~min}$ and $2 \mathrm{~h} 30 \mathrm{~min}$.

An important component to the aerial survey method was ground-truthing the patches of crops aerially identified as potentially damaged by feral swine. If feral swine were determined to be the cause by presence of tracks, scat, or rooting sign, then the area around the damage would be a focal point for thorough ground efforts to locate and eliminate feral swine in the area. Because field corn is densely planted and can reach nearly $3 \mathrm{~m}$ in height in Illinois, detection of damage would have been very difficult with surveys from the ground unless damage patches were on the edges of a field.

Another important component for aerial damage surveys was to understand if feral swine population changes affected the probabilities that a damage patch observed from the air actually would be verified as feral swine inflicted upon ground-truthing. Thus, we compared across the three aerial survey occasions the proportions of damage patches verified on the ground as swine-caused using Fisher's "exact" test.

\section{Elimination methods}

Feral swine control was initiated in Fulton County in the fall of 2009 in response to property owners seeking to reduce damage to crops by forming service agreements with WS, the Federal agency responsible for managing conflicts with wildlife ( U.S. Department of Agriculture/Animal and Plant
Health Inspection Service et al. 1997). In 2011, the IDNR executed a cooperative service agreement with WS to increase feral swine elimination efforts in Fulton County until feral swine had been eliminated from the county. Only approved and humane methods conforming to the guidelines by the American Veterinary Medical Association Panel on Euthanasia (American Veterinary Medical Association 2013) were used to euthanize animals as per agency policy (USDA/APHIS/WS Directive 2.505), with the methods also being highly acceptable to landowners (Harper et al. 2014).

The two primary methods applied to remove feral swine were trapping and targeted sharpshooting over bait. The removal method depended on observations made from trail cameras placed in areas where sighting reports were made or where damage or sign was found. The visitation frequency and number of feral swine observed on camera determined whether trapping or sharpshooting took place. Typically, if more than 2 feral swine were observed using the bait site, then corral trapping was the preferred method of removal. Otherwise, sharpshooting was the method of choice. In instances where trapping was not successful (trap shy feral swine), multiple sharpshooters were used for removal.

Aerial control from a helicopter was applied on two occasions, 11 and 12 February, as well as 24 and 25 March 2014, to accelerate removal of feral swine, mainly because feral swine remaining in the county had become difficult to locate, maintain feeding at bait sites, and/or trap. Aerial control is an efficient means to remove large numbers of feral swine in short periods of time in states of the USA where it has been practiced, especially in areas with high abundances (Bodenchuk 2014; U.S. Department of Agriculture/Animal and Plant Health Inspection Service 2016). This control method requires a certified pilot and gunner and compliance with strict federal and state laws (U.S. Department of Agriculture/Animal and Plant Health Inspection Service 2016), and was new to Illinois. Aerial control is less efficient in complex landscapes and is best conducted when foliage cover is minimal, between leaf fall and crop harvest in autumn and before re-foliation in spring (Choquenot et al. 1996; U.S. Department of Agriculture/Animal and Plant Health Inspection Service 2016), hence our February-March timeframe for aerial control. Aerial shooting in Fulton County provided a test of this approach for the fragmented habitats found there.

\section{Results}

\section{Outreach}

Outreach as well as aerial and ground surveys showed that feral swine were not pervasive throughout Fulton County. Accordingly, control work was carried out in those portions of Fulton County identified as inhabited by feral swine. The 
extent of Fulton County where control was needed comprised an area of nearly $73 \mathrm{~km}^{2}$, all of which was on private lands with assistance provided to 47 county landowners. Overall, 117 responses for technical assistance were carried out. There were 1044 leaflets, brochures, and posters distributed. There also were 40 personal consultations, 74 written/ telephone consultations, 2 instructional sessions/workshops/ demonstrations, 1 radio and television appearance, and numerous newspaper articles and exhibits such as a feral swine booth at sports shows.

\section{Aerial surveys for crop damage}

Aerial surveys for crop damage were valuable for identifying areas potentially supporting feral swine. Large tracts were surveyed in short periods of time, with most flights concluding within $2.5 \mathrm{~h}$. The extent of field corn damaged by feral swine was in relative proportion to the number of feral swine believed to still exist in Fulton County at that time. Figure 1 shows an example of how damage to field corn appears from the air. This figure also provides a good illustration of Fulton County's mixture of fragmented habitats and the abundant forest and crop resources available to feral swine.

During the 4 September 2013 aerial survey, 45 locations of possible feral swine damage to field corn were identified. Of these, 10 locations could not be visited due to landowner restrictions, 19 were confirmed as feral swine damage, 7 had damage resulting from multiple wildlife species (e.g., deer, raccoon), and 9 had damage attributed to other causes such as poor growing conditions. Therefore, of 35 damage locations accessed for ground-truthing, 54\% were confirmed to have been damaged by feral swine.

During the 16 September 2014 aerial survey, 25 potential damage locations were identified, none of which were confirmed as swine damage even though heavy rainfall the

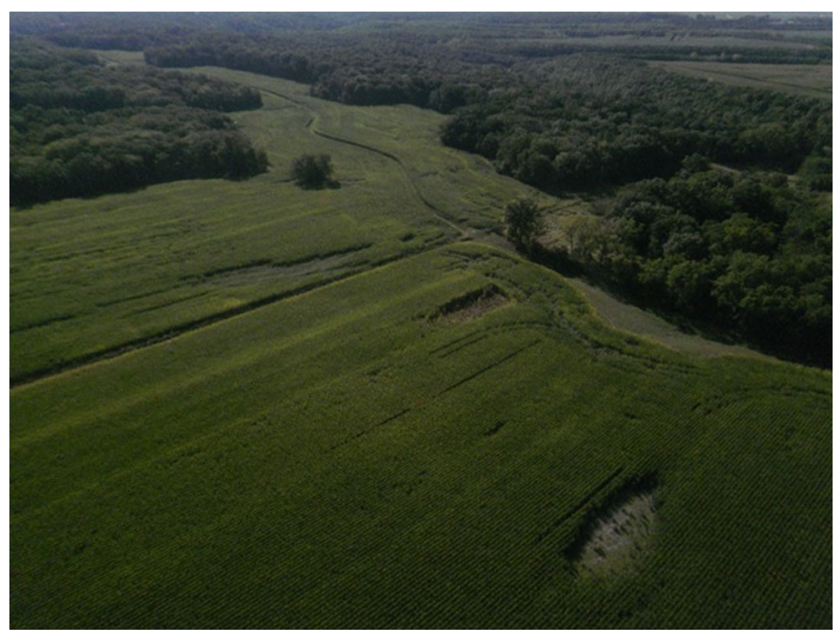

Fig. 1 Aerial view of feral swine damage patches in field corn 4 September 2013. This view also illustrates the blend of crop and forested habitat in Fulton County, Illinois previous month produced favorable soil conditions with abundant invertebrates that can attract feral swine rooting behavior. It is important to note that by this time, only one adult boar was known to exist in Fulton County. Eleven of the potential damage locations had damage from multiple wildlife species (deer and raccoon), 2 had damage from other causes (wind, water), and 12 could not be visited due to landowner restrictions (7 of which appeared most likely to be wind damage). Therefore, $0 \%$ of the potential field corn damage sites observed from the helicopter were confirmed to have been damaged by feral swine.

During the 10 August 2015 aerial survey, only 8 locations of damaged field corn were identified even though the search area was expanded to insure no nearby feral swine populations had appeared or were unobserved. Some rainfall had again produced abundant invertebrates near the soil surface, but no rooting from feral swine was observed. None of the 8 potential damage locations were confirmed as damaged by feral swine. Three locations could not be visited due to landowner restrictions or the landowner could not be contacted, although 1 of these was likely wind-caused damage and the other 2 occurred where neither feral swine nor their damage had ever been reported. Three fields had damage from multiple species of wildlife (deer and raccoon), while other causes explained the damage in 2 fields (wind, tractor/heavy equipment). Again, $0 \%$ of crop fields with potential damage observed from the helicopter were confirmed as feral swine damage.

Given the results described above, the probability that a damage patch would be verified as swine inflicted changed as the swine population decreased, $54 \%$ in 2013 and $0 \%$ in both 2014 and 2015 (Fisher's "exact" test $p<0.0001$ ).

\section{Feral swine removed}

From 2009 to 2016, 376 feral swine were removed from Fulton County. As more landowners worked in cooperation with WS and more control resources were applied, the number of feral swine removed from Fulton County rapidly increased each year to a maximum of 160 in 2012 (Table 1). After 2013, there were relatively few feral swine remaining in the county and these feral swine had become difficult to locate, attract to bait, maintain their presence at bait sites, and trap. At this point, aerial control was applied in 2014 to further reduce the population (Table 1). With further persistence in control efforts, only one boar was known to exist in Fulton County by 2015, and he was eliminated by sharpshooting in January 2016.

Overall, $60 \%$ (225) of the feral swine were removed by trapping, 30\% (112) were removed by sharpshooting, and 11\% (40) were removed by aerial control (Table 1). However, it is important to note that of the final 45 feral swine removed during the last 3 years of the effort (2014-2016), aerial control efforts represented $87 \%$ of those remaining, and they were removed in only a matter of $11.8 \mathrm{~h}$ of combined flight time. 
Table 1 Summary of the number of feral swine removed from Fulton County, Illinois, by control method from 2009 to 2016

\begin{tabular}{lllll}
\hline & Trapping & Sharpshooting & Aerial control & Total \\
\hline 2009 & 2 & 0 & 0 & 2 \\
2010 & 0 & 7 & 0 & 7 \\
2011 & 30 & 14 & 0 & 44 \\
2012 & 113 & 47 & 0 & 160 \\
2013 & 80 & 38 & 0 & 118 \\
2014 & 0 & 5 & 39 & 44 \\
2015 & 0 & 0 & 0 & 0 \\
2016 & 0 & 1 & 0 & 1 \\
Totals: & 225 & 112 & 39 & 376 \\
\hline
\end{tabular}

\section{Discussion}

The removal of 376 feral swine may seem like a large number for an incipient population. However, these removals resulted from a 7-year effort in the $73 \mathrm{~km}^{2}$ of Fulton County where control was needed, whereas in parts of the USA where feral swine have been abundant for many years, many more than 376 are removed annually without an indication that the population is being eliminated or even reduced (e.g., Higgenbotham and Bodenchuk 2014). Clearly, the removal of the feral swine population from Fulton County also removed the prospect that its relatively small population could grow and spread to the point that elimination of this highly fecund species would become much less practical, much more costly, and much more time consuming. The success at eliminating feral swine from the fragmented habitats of Fulton County proved that persistence in control efforts, integration of control methods, cooperation among stakeholders, and outreach to and education of the public can lead to a successful elimination. Moreover, valuable lessons were learned from the elimination procedures on how to conduct such a project. Since completion of the elimination, no feral swine or their sign have been detected in Fulton County. The IDNR reporting mechanisms remain in place, and direct communication with landowners in 2016 and 2017 produced no reports of feral swine sightings (directly or by trail camera), and no reports of swine damage. While Fulton County clearly cannot be considered a closed system, there were no feral swine populations close to this county ( $>150 \mathrm{~km}$ away). Thus, the only likely reinvasion route would be through illegal translocation, which IDNR regulations are aimed to persuasively deter. Elimination of feral swine from Fulton County was notable because it is a large area of mixed agriculture and forested habitat. Concurrently, pockets of feral swine were also targeted and removed from Fayette and Marion counties. At this writing, it appears that elimination of a recently discovered small pocket of feral swine in Pike County would likely rid Illinois of feral swine.
Interagency collaboration prevented duplication of efforts, empowered multiple stakeholder groups, improved communication among various agencies, and allowed for various stakeholders to have a vested interest in the outcome of the project. Aggressive public outreach assisted efforts by raising awareness regarding the feral swine problem in Illinois, how to report feral swine sightings, and obtain management assistance. This facilitated reporting of feral swine locations and promoted landowners to request assistance with removing feral swine from their land. Considering that landowners held highly negative opinions towards feral swine and feral swine threats to their lands and crops (Harper et al. 2014), control successes led to introductions and referrals from neighboring landowners for assistance in removing feral swine. As searches expanded, the knowledge that feral swine were discovered on or near neighboring properties also led to further cooperation for control activities. Furthermore, including an option to report feral swine sightings into the IDNR Mandatory Deer and Wild Turkey Harvest Reporting System assisted in locating areas that may contain feral swine. These data are maintained in a dedicated IDNR database used for tracking feral swine populations.

The IDNR also developed administrative rules that diminished the value of feral swine for recreational hunting purposes. The 2014 IDNR administrative rule (17 Ill Adm Code 700; 37 Ill Reg 19817) regulates the release, transportation, and harvest of feral swine in Illinois. This rule made shooting feral swine outside of the state's firearm deer season illegal, allowing the IDNR to more effectively manage feral swine in the state by removing the appeal of recreational hunting for feral swine during most of the year, thereby reducing their value to sportsmen. The rule's regulations against transportation and/or release of feral swine curbed prospects for translocations by humans. Translocation (illegally) is a common means by which feral swine populations are established or expanded (e.g., Tabak et al. 2017; Hernández et al. 2018; USDA 2015b), and the locations of feral swine in Illinois appeared to largely reflect where they had been released for recreational hunting (McCann et al. 2003). Further regulation diminished the general interest for feral swine hunting by requiring landowners experiencing damage to obtain a free nuisance wildlife removal permit to trap or shoot feral swine outside of the assigned season. This discouraged hunting feral swine and encouraged a professional, full-time approach to removal operations, as carried out by wildlife damage management organizations such as WS.

Conducting aerial surveys to find crop damage greatly improved the efficiency for locating feral swine. Damage to field corn was readily visible from the air; however, it was essential to conduct damage surveys during the appropriate time of the crop cycle when feral swine would most likely be damaging the crop. Surveys were conducted annually from 2013 to 2015 during the mid-August to mid-September timeframe, when we 
had observed feral swine damage to field corn to be most prevalent. If surveys for crop damage were conducted earlier when crop damage was less likely to occur, then the presence of feral swine would be unlikely to be detected in this manner. If surveys were conducted too late, the field corn would begin to dry out and be harvested or be knocked down by late summer storms. Meteorological causes (e.g., wind, flooding) for flattened field corn can make it indistinguishable from feral swine damage from the air. The entire area where control was needed was thoroughly surveyed in a little over $2 \mathrm{~h}$ of flight time, which also helped us determine if feral swine were also in locations where landowners would not allow access to their property. Even if it was possible to readily spot damage from the ground, it would have taken weeks to months to cover the same large area, with many remote or restricted access areas not being subjected to inspection. Ground-truthing of potential damage patches was essential to confirm the presence of feral swine prior to implementation of ground surveillance and removal efforts.

Aerial surveys for swine damage to corn were used strictly to identify where feral swine were present. They were not designed nor intended to estimate quantities of damage, although key principles for estimating damage amounts from the air were identified through our work. A valuable implication from our aerial surveys was that the method potentially could be an efficient means to measure crop losses from feral swine using aerial photographs and GIS methods for measuring damage, similar to the photographic method described by Engeman et al. (2016). Most of the damage patches we observed from the helicopter could not have been readily detected at ground level in 2-3-mtall field corn, unless the damage was on field edges. Another valuable lesson from our aerial surveys was the potential for difficulty in differentiating feral swine damage from other types of damage. Because our results showed that the proportion of potential damage patches observed from the air that were actually caused by feral swine was related to the feral swine population density, ground-truthing the potential damage patches observed from the air, or ground-truthing a sample of the potential damage patches, would be a critical component for estimating the amount of feral swine damage to field corn over a large area. The proportion of patches confirmed to be caused by feral swine could then be used to adjust damage estimates based on aerial observations.

The advantages of being able to cover large areas to survey for feral swine carried over to removing feral swine from a helicopter. This was especially important for rapidly eliminating many of the remaining feral swine after they had become very difficult to locate and thus eliminate. The implementation of aerial control in Illinois required several years of planning and preparation due to the complex regulatory and logistical prerequisites that had to be met. Earlier implementation likely would have more rapidly reduced the county's feral swine population.
Locating the last few remaining members of a population is usually a difficult task. In our case, aerial surveys provided essential information to guide our searches for feral swine sign and where to thoroughly distribute trail cameras to detect and roughly quantity the remaining animals. Cameras were not used for estimating population size or trends. Rather, their use was strictly to locate feral swine to facilitate their removal. For the purposes of finding the last few feral swine or detecting the first few members of a new incursion, a variety of other methods are available. For example, analysis of environmental DNA (eDNA) has been applied to detect invasive species (e.g., Piaggio et al. 2014) and is being developed for the detection of feral swine (Williams et al. 2017). Most likely, water samples would be analyzed to take advantage of feral swine affinity for wet environments. However, false positives are possible due to the presence of domestic animals, discarded carcasses, or other domestic swine remains. In some instances, trained dogs could be used to detect and locate feral swine if they can be put on a scent, although false positives from domestic swine could occur. Bait piles with cameras could be used in standardized surveys even if feral swine have not been seen or reported. Also, "Judas swine" may be used to locate feral swine known or suspected to be in an area (e.g., West et al. 2009), although this process requires the capture, collaring, release, and personnel to monitor the animal. In fact, for our Fulton County work, we purchased all the tools necessary to employ the "Judas animal" technique, but we did not need to use it because our other efforts proved successful at removing the last feral swine prior to employing this methodology. Intensive outreach to the public, especially hunters and farmers, as conducted by the IDNR and WS, puts many "eyes on the ground" aware of the importance to report feral swine and significantly assists agencies involved in feral swine elimination efforts by identifying where the animals exist and focusing removal efforts at specific locations.

\section{References}

American Veterinary Medical Association (2013) AVMA guidelines for the euthanasia of animals: 2013 edition. American Veterinary Medical Association, Schaumburg

Barrios-Garcia MN, Ballari SA (2012) Impact of wild boar (Sus scrofa) in its introduced and native range: a review. Biol Invasions 14:22832300

Bieber C, Ruf T (2005) Population dynamics in wild boar Sus scrofa: ecology, elasticity of growth rate and implications for the management of pulsed resource consumers. J Appl Ecol 42:1203-1213

Bodenchuk MJ (2014) Method-specific costs of feral swine removal in a large meta-population: the Texas experience. In: Timm RM, O'Brien JM (eds) Proc. 26th Vertebr. Pest Conf. Univ. California, Davis vol 26, pp 269-271

Choquenot D, McIlroy J, Korn T (1996) Managing vertebrate pests: feral pigs. Bureau of Resource Sciences, Australian Government Publishing Service, Canberra ACT 
Corn JL, Jordan TR (2018) Development of the national feral swine map, 1982-2016. Wildl Soc Bull 41(4):758-763

Engeman RM, Stevens A, Allen J, Dunlap J, Daniel M, Teague D, Constantin BU (2007) Feral swine management for conservation of an imperiled wetland habitat: Florida's vanishing seepage slopes. Biol Conserv 134:440-446

Engeman RM, Couturier KJ, Felix RK Jr, Avery ML (2013a) Feral swine disturbance at important archaeological sites in Florida. Environ Sci Pollut Res 20:4093-4098

Engeman RM, Massei G, Sage M, Gentle M (2013b) Monitoring wild pig populations: a review of methods. Environ Sci Pollut Res 20:80778091

Engeman RM, Cattaruzza M, Cattaruzza R, Fischer J (2016) Photographic estimation of wild boar damage to alpine grazing pastures in the Carpathian Mountains of central Romania. Environ Sci Pollut Res 23:4949-4952

Engeman RM, Meyer JS, Allen JB (2017) Prevalence of feral swine disturbance at important archaeological sites over a large area in Florida. Sci Rep (Nature) 7:40287

Esker TL (2001) Distribution and status of feral hogs in Illinois. Abstract, Illinois Renewable Natural Resources Conference, Peoria

Grund MD, Thogmartin WE, Woolf A (2000) A preliminary assessment of feral hogs in southern Illinois. Cooperative Wildlife Research Lab, Southern Illinois University, Carbondale

Harper EE, Miller CA, Stephenson AL, McCleary ME, Campbell LK (2014) Landowner attitudes and perceived risks toward wild pigs on private lands in Illinois. Job completion report, Federal Aid in Wildlife Restoration W-112-R-22. Human Dimensions Research Program Report HR-14-05. INHS Technical Report 2014 (16). Illinois Natural History Survey, Champaign

Hernández FA, Parker BM, Pylant CL, Smyser TJ, Piaggio AJ, Lance SL, Milleson MP, Austin JD, Wisely SM (2018) Invasion ecology of wild pigs (Sus scrofa) in Florida, USA: the role of humans in the expansion and colonization of an invasive wild ungulate. Biol Invasions 20:1865-1880

Higgenbotham B, Bodenchuk MJ (2014) Wild pig damage abatement in Texas: an integrated strategy of landowner education and direct control. In: Timm RM, O'Brien JM (eds) Proc. 26th Vertebr. Pest Conf. Univ. of Calif., Davis, pp 243-257

Leiser OP, Corn JL, Schmit BS, Keim PS, Foster JT (2013) Feral swine brucellosis in the United States and prospective genomic techniques for disease epidemiology. Vet Microbiol 166:1-10

Lowe S, Browne M, Boudjelas S, De Poorter M (2004) 100 of the world's worst invasive alien species: a selection from the Global Invasive Species Database. Invasive Species Specialist Group, Auckland

McCann B, Davie DK, Feldhamer GA (2003) Distribution, habitat use, and morphotypes of feral hogs (Sus scrofa) in Illinois. Trans Illinois State Acad Sci 96:301-311
Piaggio AJ, Engeman RM, Hopken MW, Humphrey JS, Keacher KL, Bruce WE, Avery ML (2014) Detecting an elusive invasive species: a diagnostic PCR to detect Burmese python in Florida waters and an assessment of persistence of environmental DNA. Mol Ecol Resour $14: 374-380$

U.S. Department of Agriculture/Animal and Plant Health Inspection Service, U.S. Department of Agriculture/Forest Service and Department of Interior/Bureau of Land Management (1997) Animal damage control program final environmental impact statement (revised). USDA/Animal and Plant Health Inspection Service, Washington, D.C.

Seward N, VerCauteren K, Witmer G, Engeman R (2004) Feral swine impacts on agriculture and the environment. Sheep and Goat Res J 19:34-40

Snow NP, Jarzyna MA, VerCauteren KC (2017) Interpreting and predicting the spread of invasive wild pigs. J Appl Ecol 54:20222032

Tabak MA, Piaggio AJ, Miller RS, Sweitzer RA, Ernest HB (2017) Anthropogenic factors predict movement of an invasive species. Ecosphere 8(6): 01844

U.S. Department of Agriculture (2016) Feral swine: damages, disease threats, and other risks. Animal and Plant Health Inspection Services Program Aid 2195b. Washington, DC

U.S. Department of Agriculture/Animal and Plant Health Inspection Service (2015a) APHIS national feral swine damage management program operational component funding structure. APHIS national feral swine damage management program. Fort Collins, CO.

U.S. Department of Agriculture/Animal and Plant Health Inspection Service (2015b) Final environmental impact statement feral swine damage management: a national approach. USDA/Animal and Plant Health Inspection Service, Washington, D.C.

U.S. Department of Agriculture/Animal and Plant Health Inspection Service (2016) Feral swine management methods guide: strategies for the capture and removal of an invasive species. National Feral Swine Damage Management Program, Fort Collins

US Bureau of the Census (1991) Statistical abstract of the United States, 11 th edn. Washington, DC

Webb CT, Burdett CL, Miller RS. (2018) Predicting wild pig population establishment following introduction into a new location. Wild pig conference science, management \& solutions, pp 24

West BC, Cooper AL, Armstrong JB (2009) Managing wild pigs: A technical guide. Human-Wildlife Interactions 1:1-55

Williams K, Huyvaert K, Vercauteren KC, Davis AJ, Piaggio A (2017) Detection and persistence of environmental DNA from an invasive, terrestrial mammal. Ecol Evol 8:688-695

Wyckoff AC, Henke SE, Campbell TA, Hewitt DG, VerCauteren KC (2009) Feral swine contact with domestic swine: a serologic survey and assessment of potential for disease transmission. J Wildl Dis 45: 422-429 